\title{
The possible haematological effects of glycol monomethyl ether in a frame factory
}

\author{
Francesca Larese, Antonio Fiorito, Renata De Zotti
}

\begin{abstract}
Haemopoietic effects of ethylene glycol monomethyl ether (EGME) are described in three young women employed in a frame factory where the substance was applied under apparently safe hygienic conditions. In a ventilated room they used a mixture of acetone $(70 \%)$ and EGME (30\%) to glue together cellulose acetate frame components. During a periodic medical examination their white blood cell count was found to be abnormally low, with a relative lymphocytosis, macrocytosis with red blood cells, and haemoglobin at borderline normal values. These findings persisted over the exposure period but the haematological parameters returned to normal on stopping exposure. The subjects remained clinically healthy during the exposure period. This exposure to EGME occurred in an industry where such toxicity had not been previously reported and describes a situation in which the risk did not come from the exposure to vapour but most likely from an insufficient skin protection.
\end{abstract}

Ethylene glycol monomethyl ether (EGME; meticellosolve) is a volatile and almost odourless solvent used primarily as an industrial solvent for resins, paints, dyes, and lacquers. ${ }^{1}$

The first report describing acute effects of short term exosure concerns its use as a cleaning solvent in the production of fused shirt collars. ${ }^{23}$ Later reports have determined its toxicity for several animal species: the main actions are on the brain, blood, and kidney. ${ }^{45}$ Some cases of acute or subacute poisoning have been described in human subjects, due to ingestion or to high environmental exposure, ${ }^{6-12}$ but recently some authors have suggested that cutaneous absorption may play a significant part in poisoning in humans. ${ }^{1314}$

Istituto di Medicina del Lavoro, University of Trieste, Via Pieta 19, 34100 Trieste, Italy

F Larese, A Fiorito, $R$ De Zotti
We describe haemopoietic effects of EGME in three workers employed in a glasses frame factory where the substance was used under apparently hygienic safe conditions.

\section{Work environment and exposure}

The affected workers were employed by a factory where celluloid glasses frames were made. They dipped the pieces to be fixed together in a kettle containing a mixture of acetone (70\%) and EGME (30\%); then glued them by cold pressing the two melted edges. They worked in a ventilated room standing directly over an aspirated table. Thin rubber gloves were worn but sometimes they handled the smallest pieces with bare hands, getting the solvent on their fingertips.

Unfortunately the EGME was replaced before we could measure the concentration the workers were exposed to, but the environmental concentrations of acetone, which is much more volatile than EGME and which was the main component $(70 \%)$ of the solvent mixture, were unremarkable.

As the amount of the substance used was 11 /day and we did not find excessive acetone in the environment, we assumed that EGME concentrations in the air were also negligible.

\section{Case reports}

Three young women employed in assembling glasses frames had their first periodic medical examination in 1987, two years after beginning their jobs.

The clinical histories of the patients were negative; they did not suffer from virus infections, did not complain of any symptoms during work, had no feelings of depression or other neurological symptoms, and no skin or mucosae irritation. Physical examination showed no abnormalities, the results from neurological examination were normal, and no dermatitis was found. At the time of examination (August 1987) their white blood cell counts were low, with a relative increase in lymphocytes in the differential counts. 
Table 1 Periodic haematological and chemical findings

\begin{tabular}{|c|c|c|c|c|c|c|c|c|c|c|c|c|}
\hline \multirow{4}{*}{$\begin{array}{l}\text { Date } \\
\mathrm{Hb}(\mathrm{g} / \mathrm{dl})(12-16)^{\star} \\
\mathrm{RBC}\left(\times 10^{12} / 1\right) \\
(4 \cdot 4-5 \cdot 4) \\
\mathrm{MCV}(\mathrm{fl})(78-86) \\
\operatorname{MCH}(\mathrm{pg})(26-33) \\
\text { WBC }\left(\times 10^{9} / 1\right)\end{array}$} & \multicolumn{4}{|c|}{ Case 1: VP aged 28} & \multicolumn{4}{|c|}{ Case 2: $S O$ aged 23} & \multicolumn{4}{|c|}{ Case 3: SL aged 22} \\
\hline & \multicolumn{3}{|c|}{ During exposure } & \multirow{2}{*}{$\begin{array}{l}\begin{array}{l}\text { Ceased } \\
\text { exposure }\end{array} \\
\text { Mar } 89 \\
13 \cdot 3\end{array}$} & \multicolumn{3}{|c|}{ During exposure } & \multirow{2}{*}{$\begin{array}{l}\begin{array}{l}\text { Ceased } \\
\text { exposure }\end{array} \\
\text { Mar } 89 \\
12 \cdot 9\end{array}$} & \multicolumn{3}{|c|}{ During exposure } & \multirow{2}{*}{$\begin{array}{l}\begin{array}{l}\text { Ceased } \\
\text { exposure }\end{array} \\
\text { Mar } 89 \\
13 \cdot 7\end{array}$} \\
\hline & $\begin{array}{l}\text { Aug } 87 \\
13 \cdot 6\end{array}$ & $\begin{array}{l}\operatorname{Jan} 88 \\
14 \cdot 1\end{array}$ & $\begin{array}{l}\text { Mar } 88 \\
14 \cdot 2\end{array}$ & & $\begin{array}{l}\text { Aug } 87 \\
12 \cdot 2\end{array}$ & $\begin{array}{l}\operatorname{Jan} 88 \\
12 \cdot 6\end{array}$ & $\begin{array}{l}\text { Mar } 88 \\
12 \cdot 3\end{array}$ & & $\begin{array}{l}\text { Aug } 87 \\
11 \cdot 8\end{array}$ & $\begin{array}{l}\text { Jan } 88 \\
11 \cdot 3\end{array}$ & $\begin{array}{l}\text { Mar } 88 \\
12 \cdot 3\end{array}$ & \\
\hline & $\begin{array}{l}4 \cdot 1 \\
99 \\
33\end{array}$ & $\begin{array}{l}4 \cdot 2 \\
98 \\
32 \cdot 3\end{array}$ & $\begin{array}{l}4 \cdot 3 \\
97 \\
32 \cdot 3\end{array}$ & $\begin{array}{l}4 \cdot 1 \\
92 \\
32 \cdot 1\end{array}$ & $\begin{array}{l}3.5 \\
97 \\
-\end{array}$ & $\begin{array}{l}4 \cdot 1 \\
96 \cdot 1 \\
30 \cdot 7\end{array}$ & $\begin{array}{l}4 \cdot 1 \\
94 \cdot 9 \\
29 \cdot 7\end{array}$ & $\begin{array}{l}4 \cdot 3 \\
91 \cdot 4 \\
29 \cdot 9\end{array}$ & $\begin{array}{l}3 \cdot 2 \\
100 \\
-\end{array}$ & $\begin{array}{l}4 \cdot 2 \\
97 \cdot 8 \\
31 \cdot 4\end{array}$ & $\begin{array}{l}3 \cdot 8 \\
108 \cdot 0 \\
32 \cdot 4\end{array}$ & $\begin{array}{l}4 \cdot 5 \\
91 \cdot 5 \\
30 \cdot 5\end{array}$ \\
\hline $\begin{array}{l}\text { WBC }\left(\times 10^{9} / 1\right) \\
(4 \cdot 5-10) \\
\text { N }(\%) \\
\text { L }(\%) \\
\text { E (\%) } \\
\text { B (\%) } \\
\text { M (\%) }\end{array}$ & $\begin{array}{l}6 \cdot 1 \\
50 \\
49 \\
- \\
1\end{array}$ & $\begin{array}{l}5 \cdot 5 \\
43 \\
49 \\
2 \\
1 \\
5\end{array}$ & $\begin{array}{l}4 \cdot 5 \\
31 \\
56 \\
8 \\
5\end{array}$ & $\begin{array}{l}7 \cdot 4 \\
47 \\
43 \\
4 \\
5\end{array}$ & $\begin{array}{l}6 \cdot 8 \\
43 \\
49 \\
4 \\
1 \\
3\end{array}$ & $\begin{array}{l}5 \cdot 9 \\
43 \cdot 4 \\
44 \cdot 5 \\
3 \cdot 1 \\
1 \cdot 2 \\
7 \cdot 4\end{array}$ & $\begin{array}{l}5 \cdot 9 \\
41 \cdot 7 \\
45 \cdot 8 \\
6 \cdot 3 \\
1 \cdot 1 \\
4 \cdot 7\end{array}$ & $\begin{array}{l}7 \cdot 6 \\
57 \cdot 8 \\
31 \cdot 4 \\
4 \cdot 2 \\
0 \cdot 9 \\
4 \cdot 9\end{array}$ & $\begin{array}{l}5 \cdot 1 \\
32 \\
63 \\
1 \\
1 \\
3\end{array}$ & $\begin{array}{l}4 \cdot 5 \\
41 \cdot 2 \\
45 \cdot 1 \\
1 \cdot 5 \\
0 \cdot 9 \\
11 \cdot 1\end{array}$ & $\begin{array}{l}3 \cdot 4 \\
48 \cdot 8 \\
41 \cdot 8 \\
2 \cdot 5 \\
0 \cdot 6 \\
6 \cdot 1\end{array}$ & $\begin{array}{l}4 \cdot 4 \\
49 \\
36 \cdot 6 \\
3 \cdot 3 \\
0 \cdot 2 \\
10 \cdot 3\end{array}$ \\
\hline $\begin{array}{l}\text { Platelets }\left(\times 10^{9} / 1\right) \\
\quad(150-400) \\
\text { Iron }(\mathrm{g} / \mathrm{dl})(40-150)\end{array}$ & $\underline{220}$ & $\begin{array}{l}221 \\
150\end{array}$ & $\begin{array}{l}192 \\
120\end{array}$ & $\begin{array}{l}191 \\
80\end{array}$ & $\frac{220}{-}$ & $\begin{array}{l}221 \\
150\end{array}$ & $\begin{array}{l}218 \\
71\end{array}$ & $\begin{array}{l}265 \\
117\end{array}$ & 二 & $\begin{array}{l}205 \\
108\end{array}$ & $\begin{array}{l}256 \\
107\end{array}$ & $\frac{208}{-}$ \\
\hline $\begin{array}{l}\text { Vitamin } B_{12}(\mathrm{pg} / \mathrm{ml}) \\
(160-970) \\
\text { Folate-serum }(\mathrm{ng} / \mathrm{ml})\end{array}$ & - & - & 718 & - & - & - & 465 & - & - & - & 369 & - \\
\hline Folate-RBC (ng/ml) & - & 一 & $4 \cdot 3$ & - & - & - & $5 \cdot 2$ & - & - & - & 3.9 & - \\
\hline $\begin{array}{l}(120-860) \\
\text { AST }(U / 1)(<29) \\
\text { ALT }(U / 1)(<29) \\
\text { GGT (mU/1)(<25) }\end{array}$ & $\begin{array}{l}- \\
9 \\
10 \\
7\end{array}$ & $\begin{array}{l}\overline{-} \\
\overline{-}\end{array}$ & $\begin{array}{l}354 \\
9 \\
9 \\
7\end{array}$ & $\begin{array}{l}-\overline{8} \\
6 \\
6\end{array}$ & $\begin{array}{l}-\overline{21} \\
15 \\
29\end{array}$ & $\frac{-}{-}$ & $\begin{array}{l}376 \\
10 \\
10 \\
7\end{array}$ & $\begin{array}{l}-13 \\
8 \\
-\end{array}$ & $\begin{array}{l}\overline{15} \\
15 \\
20\end{array}$ & $\begin{array}{l}-7 \\
6 \\
8\end{array}$ & $\begin{array}{l}346 \\
11 \\
11 \\
8\end{array}$ & $\begin{array}{l}\overline{17} \\
5 \\
10\end{array}$ \\
\hline
\end{tabular}

$\mathrm{HB}=$ Haemoglobin concentration; RBC $=$ red blood cell count; $\mathrm{MCV}=$ mean corpuscular volume; $\mathrm{MCH}=$ mean corpuscular haemoglobin; $\mathbf{W B C}=$ white blood cell count; $\mathrm{AST}=$ aspartate aminotransferase; ALT $=$ alanine aminotransferase; GGT $=\gamma-$ glutamyltransferase.

${ }_{\star}$ Normal ranges in parentheses.

There was a macrocytosis (mean corpuscular volume $(\mathrm{MCV})>95 \mathrm{fl})$ with the red blood cell counts and haemoglobin concentrations at borderline values. Liver and kidney function, platelet numbers, vitamin B12, folate, and blood iron concentrations were all normal (table 1). No IgG and IgM antibodies against Epstein Barr virus were found. During the period of occupational exposure, we also evaluated the lymphocyte subpopulations. These were normal (table 2).

The patients continued in their jobs as they considered themselves well. Haematological abnormalities were confirmed by two examinations some months later and the women were removed from exposure to EGME. Figures 1, 2, and 3 report haematological findings during exposure, when exposure finished, and one year after exposure. There was a decrease in white blood cell count, mainly neutrophils, during exposure. The differential count showed an increased proportion of lymphocytes. The haematological examination carried out one year after they had left the job showed in two cases an increase in white blood cell count and a normal

Table 2 T lymphocyte types found during exposure (subsets of $T$ cells are identified from cell surface antigens detected by using a panel of monoclonal antibodies)

\begin{tabular}{lllll}
\hline$T$ cell subsets & $V P$ & $S O$ & $S L$ & Reference range \\
\hline OKT3 $(\%)$ & 74 & 83 & 67 & $60-70$ \\
OKT4 $(\%)$ & 43 & 51 & 49 & $40-50$ \\
OKT8 $(\%)$ & 33 & 32 & 21 & $20-30$ \\
\hline
\end{tabular}

differential count. Two years were necessary to normalise the leucocyte count in one case.

\section{Discussion}

It is known that acute poisoning by EGME through oral and respiratory routes affects the central nervous system and causes renal failure. The poisoning is often associated with abnormalities in blood..$^{7-10}$ Macrocytic anaemia and an abnormal leucocyte picture have also been described in subacute poisoning, but they are usually associated with reversible subjective central nervous system complaints. ${ }^{8}$

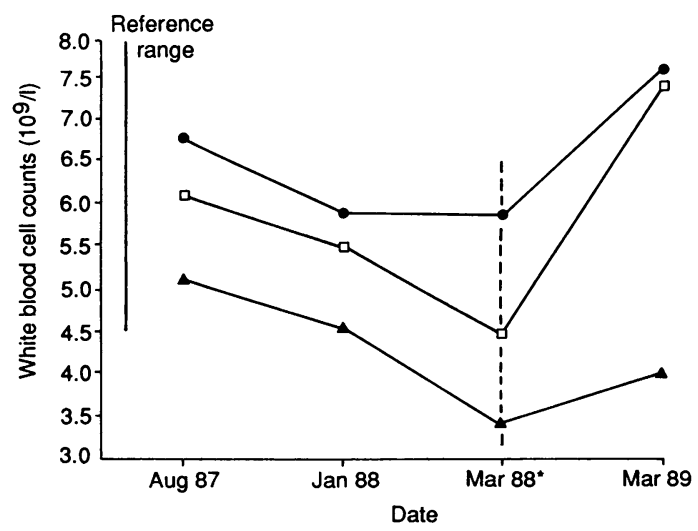

Figure 1 White blood cell counts for three patients during and one year after exposure to EGME. ${ }^{\star}$ End of exposure. 


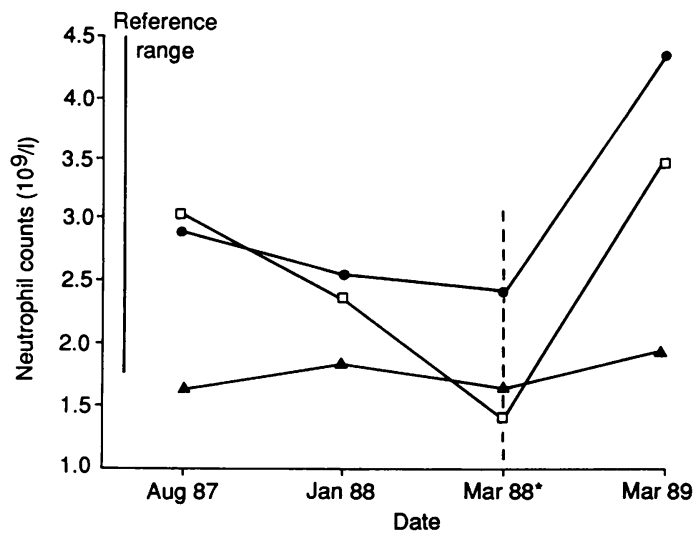

Figure 2 Neutrophil counts for three patients during and one year after exposure to EGME. ${ }^{\star}$ End of exposure.

During exposure to EGME our cases showed, as reported by other authors, ${ }^{8-13}$ a mild macrocytic anaemia and leucopenia with an increased proportion of lymphocytes in otherwise healthy workers: we found normal blood iron, bilirubinaemia, reticulocytes, and platelets and can exclude a systemic toxicity because liver and kidney function were normal. Unlike other authors ${ }^{1-13}$ we did not find neurological symptoms. Nevertheless we think that these findings indicate a form of EGME poisoning, especially because the haematological changes were transitory, repeatedly documented during the exposure period, but reversible after stopping exposure.

The toxicological experience in human subjects usually comes from situations with poor hygienic controls and where inhalation of vapours is associated with skin contact; no reports exist for such risk in the glasses frame production industry. In the factory studied here the amount of EGME acetone mixture used was very small. The ventilation system was efficient as we did not detect acetone in the air.

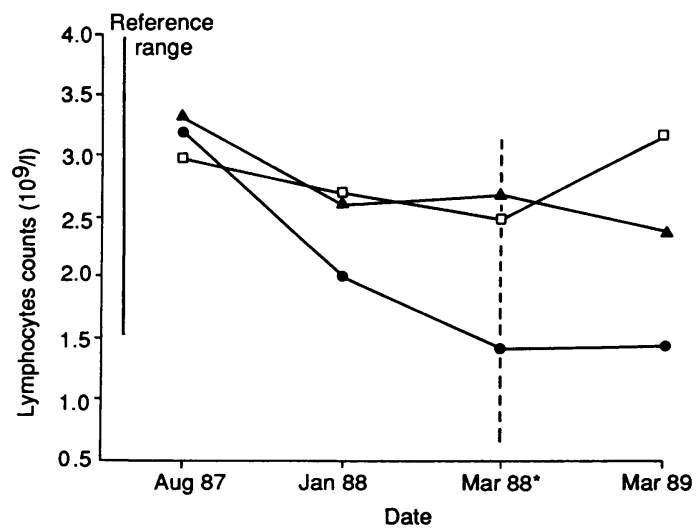

Figure 3 Lymphocyte counts for three patients during and one year after exposure to EGME. ${ }^{\star}$ End of exposure.
We argue that in the described cases cutaneous absorption has been the main and perhaps the sole route of intake. We believe that the haematological disorders in the three women were due to a chronic absorption caused by working with bare hands from time to time, or by using inadequate protection. We point out that EGME not only penetrates human skin over three times more efficiently than other glycols and more efficiently than ethanol, with a rate of $2.83 \mathrm{mg} / \mathrm{cm}^{2} /$ hour but also that some rubber gloves do not give a suitable protection to the skin. ${ }^{14}$

In conclusion, EGME can induce reversible toxic effects and blood seems to be the main target in cases of chronic exposure. It appears that it is not sufficient just to monitor the environmental conditions to prevent inhalation of vapour, but, as stated by the American Conference of Governmental Industrial Hygienists ${ }^{1516}$ prevention of skin absorption by avoiding skin contact and using suitable gloves must be compulsory.

1 Rowe VK. Derivatives of glycols. In: Patty's industrial hygiene and toxicology. New York: J Wiley, 1963;II:1543-7.

2 Parsons CE, Parson MEM. Toxic encephalopathy and granulopenic anaemia due to volatile solvents in industry: report of two cases. Journal of Industrial Hygiene and Toxicology 1938;20:124-33.

3 Greenburg L, Mayers MR, Goldwater LJ, Burke WK, Moskowitz S. Health hazards in the manufacture of fused collars I. Exposure to ethlene glycol monomethyl ether. Journal of Industrial Hygiene and Toxicology 1938;20:134-47.

4 Samuels DM, Doe JE, Tinston DJ. The effects on the rat testis of single inhalation exposure to ethylene glycol monoalkyl ethers, in particular ethylene glycol monomethyl ether. Archives of Toxicology 1984;7(suppl):167-70.

5 Foster PM, Creasy DM, Foster JR, Cook LV, Gangolli SD. Testicular toxicity of ethylene glycol monomethyl and monoethyl ethers in the rat. Toxicol Appl Pharmacol 1983;69: 385-99.

6 Werner HW, Mitchell JW, von Ottingen WF. The acute toxicity of vapours of several monoalkyl ethers of ethylene glycol. Journal of Industrial Hygiene and Toxicology 1943;25:157-63.

7 Donley DE. Toxic encephalopathy and volatile solvents in industry. Report of a case. Journal of Industrial Hygiene and Toxicology 1936;18:134-6.

8 Pastenbach DJ. Assessment of the developmental risks resulting from occupational exposure to select glycol ethers within the semiconductor industry. J Toxicol Environ Health 1988; 23:29-75.

9 Zavon MR. Methyl cellosolve intoxication. Am Ind Hyg Assoc J 1963;24:36-41.

10 Young EG, Wooner LB. A case of fatal poisoning from 2methoxyethanol. Journal of Industrial Hygiene and Toxicology 1946;28:267-8.

11 Cohen R. Reversible subacute ethylene glycol monomethyl ether toxicity associated with microfilm production: A case report. Am J Ind Med 1984;6:441-6.

12 Nitter-Hauge S. Poisoning with ethylene glycol monomethyl ether. Report of two cases. Acta Medica Scandinavica 1970; 188:277-80.

13 Ohi G, Wegman DH. Transcutaneous ethylene glycol monomethyl ether poisoning in the work setting. $J$ Occup Med 1978;20:675-6.

14 Dugard PH, Walker M, Mawdsley SJ, Scott RC. Absorption of some glycol ethers through human skin in vitro. Environ Health Perspect 1984;57:193-8.

15 American Conference of Governmental Industrial Hygienists. Threshold limit value for chemical substances and physical agents in the workroom environment with intended changes for 1986-7. Cincinnati, Ohio: ACGIH, 1986.

16 American Conference of Governmental Industrial Hygienists. Documentation of threshold limit values and biological exposure indices, 5th ed. Cincinnati, Ohio: ACGIH, 1986

Accepted 19 June 1991. 